\title{
MORPHOLOGICAL CHARACTERISTICS AND VARIATION OF GUDGEON, GOBIO GOBIO (ACTINOPTERYGII: CYPRINIDAE), FROM THE ODRA RIVER DRAINAGE, POLAND
}

\author{
Jolanta SZLACHCIAK* and Dorota ZABBKIEWICZ
}

\author{
Division of Zoology, University of Warmia and Mazury, Olsztyn, Poland
}

\begin{abstract}
Szlachciak J., Ząbkiewicz D. 2008. Morphological characteristics and variation of gudgeon, Gobio gobio (Actinopterygii: Cyprinidae), from the Odra River drainage, Poland. Acta Ichthyol. Piscat. 38 (1): 9-19.
\end{abstract}

\begin{abstract}
Background. The gudgeon is a small fish of limited economic importance. Species of the genus Gobio bear a strong superficial resemblance to one each other, what has led to the misidentification of Central European gudgeons for many years. Consequently, accurate information about Polish populations of gudgeon is still scarce and more studies are needed to fill this gap. The purpose of the presently reported study is to describe the gudgeon on the basis of its morphological characters and to compare the results published by other authors.

Materials and Methods. A total of 46 specimens of the gudgeon, Gobio gobio, were caught in the Zimnik Stream, the Skóra system, the Odra River drainage, western Poland, in October 2002. For each fish, 24 biometric features of the body and 20 features of the skull were measured. Selected meristic features (external and internal) were determined. Cephalic sensory canals were studied and their pores were counted.

Results. The coefficient of variation for the body proportions of the sample of gudgeon from the Odra River drainage ranges from $1.7 \%$ to $7.2 \%$ and its principal features are as follows: $D$ III $7-9 ; A$ III 6-7; $P$ I 11-15; $V$ I $6-8 ;$ l.l. 37-41. Two rows of pharyngeal teeth are present, most frequently, in $2.5-5.2$ pattern. The total number of vertebrae ranges from 46 to 48 (mean 47.38).

Conclusions. This study shows that the sample analyzed has the shortest head length in relation to other measurements and the body length, as compared to other populations from Polish rivers. The majority of values of meristic features do not differ significantly from those found in literature. The presently provided internal meristic and osteological features of gudgeon are among very few such data available.
\end{abstract}

Keywords: fish, gudgeon, Gobio gobio, meristics, biometry, osteology

\section{INTRODUCTION}

Gudgeon, Gobio gobio (Linnaeus, 1758) belongs to the genus Gobio, subfamily Gobioninae, one of the major subfamilies in the Cyprinidae (cf. Nelson 2006). Gobionines typically include many bottom dwellers of small to medium sized fish and are abundant in East Asia. General characteristics of species of this subfamily are: the elongate- or rather oblong cylindrical bodies, an inferior mouth, and a pair of barbels (Hosoya 1986).

Their morphological and ecological diversity caused a debate about which genera should be included in the Gobioninae and whether this subfamily constitutes a monophyletic group within the Cyprinidae (cf. Yang et al. 2006).

The subfamily Gobioninae consists of two major phyletic lineages. The first one includes semi-bottom dwellers such as Hemibarbus, Squalius, Gobio, and Mesogobio, the second one including true bottom dwellers such as Gobiobotia, Pseudogobio, Saurogobio, Microphysogobio, and Biwia (cf. Hosoya 1986).
Gobionins include approximately 130 species in about 30 genera that are widely distributed throughout northern and eastern Eurasia from Spain east to Japan and south to central Vietnam. The genus Gobio is a small fish of low economic importance, and therefore has hitherto received little attention (Callejas et al. 2004).

For a long time gudgeons were thought to belong to a frequently found, polymorphic species Gobio gobio (cf. Bănărescu 1992, Naseka 1998, Bănărescu et al. 1999). This diversity has led to the misidentification of Central Europe gudgeons for many years (Freyhof et al. 2000).

At present, approximately 20 Gobio species is distributed through Europe and Asia (Doadrio and Madeira 2004), nine species only in Europe (Naseka and Bogutskaya 1998, Ruchin and Naseka 2003). Three species, G. gobio, G. kessleri, and G. albipinnatus, occurring in Poland, have been traditionally assigned to this genus.

The gudgeon, G. gobio is widely distributed in Europe except some parts of Spain, southern Italy, and Greece as

\footnotetext{
* Correspondence: Dr Jolanta Szlachciak, Katedra Zoologii, Wydział Biologii, Uniwersytet Warmińsko-Mazurski, ul. Oczapowskiego 5, 10-957 Olsztyn, Poland, phone: +48 89 523-3734, fax: +48 89 523-3261, e-mail: jolasz@uwm.edu.pl
} 
well as north Scandinavia. According to Bănărescu (1992), 15 species are considered valid. G. gobio from Europe, Siberia, and Central Asia represents Gobio sensu stricto (cf. Bănărescu 1999). Following the arguments put forward by Vasil'eva et al. (2004, 2005) and Vasil'eva and Kuga (2005) it was suggested by Nowak et al. (2006, 2008 ) to treat the common gudgeon populations from the Vistula River drainage as Gobio gobio (L.) sensu lato (G. gobio (L.) complex).

G. gobio is considered to be an eurybiontic species inhabiting creeks, rivers, lakes, and ponds of different sizes and preferring slowly flowing waters (Ruchin and Naseka 2003). Some of the morphometric characters show the high variability. Bănărescu (1954), based on his own studies, demonstrated the existence of two ecological forms, rheophilus and limnophilus. Rheophilus morphotypes have a longer tail peduncle, more deeply forked caudal fins, longer paired fins and barbels, and are darker than the limnophilus forms from the same general area, which have a higher body shape and rounded caudal fins (Bănărescu et al. 1999).

Recently published taxonomic revisions (Vasil'eva et al. 2004, 2005, Naseka et al. 2006) revealed that some of the presently known subspecies or local forms should be regarded as separate species.

There are few papers dealing with the accurate information about Polish populations of gudgeon. Biometric studies were carried out on gudgeon, G. gobio, from the rivers of southern Poland (Skóra and Włodek 1966, 1969, 1971), from the Vistula drainage (Rolik 1965), and from two small rivers in the Vistula River drainage (Nowak et al. 2008). Kirtiklis et al. (2005) studied the karyotype of G. gobio from the Odra River.

The aim of this contribution is to describe the morphology of gudgeon from the Odra River drainage, based on its meristic and metric characters, with special emphasis on some osteological features. A comparison with specimens and populations from other regions of Poland could provide new data on the intraspecific variability and help to identify characteristic differences among the populations.

\section{MATERIALS AND METHODS}

A total of $46 \mathrm{G}$. gobio individuals were collected in October 2002 from the population inhabiting the Zimnik Stream, the Skóra River System in the Odra River drainage (Fig. 1). Twenty-four metric features were analyzed following the methodology of Szlachciak (2000) (except for some abbreviations) and measured to the nearest $0.1 \mathrm{~mm}$ on the left side of the body: head length $(l c)$, preorbital distance $(\mathrm{prO})$, eye diameter $(O)$, postorbital distance $(p o O)$, head depth $(h c)$, head width (lac), lower jaw length $(l m d)$, barbel length $(l b)$, standard length (SL), predorsal distance $(p D)$, postdorsal distance $(p o D)$, maximum body depth $(H)$, minimum body depth $(h)$, preanal distance $(p A)$, caudal peduncle length $(l p c)$, body width $($ laco $)$, pectoral fin length $(l P)$, ventral fin length $(l V)$, dorsal fin length $(l D)$, anal fin length $(l A)$, dorsal fin height $(h D)$, anal fin height $(h A)$, distance between pectoral and

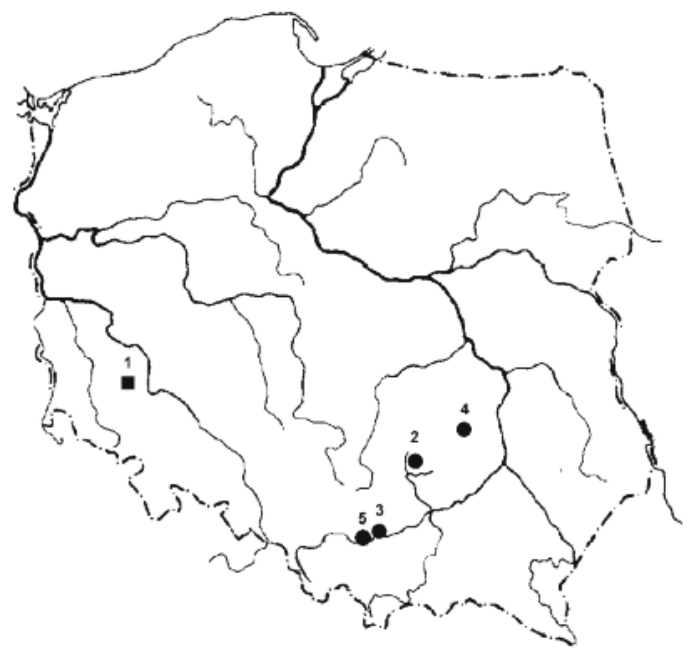

Fig. 1. The location of the sampling site of gudgeon, Gobio gobio, from the Odra River drainage (1) and those found in literature; Silnica River (2), Rudawa River (3) (Nowak et al. 2008); Kamienna River (4), Czarna Staszowska River (5) (Skóra and Włodek 1971)

ventral fin $(\mathrm{P}-\mathrm{V})$, distance between ventral and anal fin $(\mathrm{V}-\mathrm{A})$. The measurements were expressed as a percentage of the standard length (SL) and head length $(l c)$. The following meristic features (external and internal) were analysed: soft (branched) fin ray numbers of: dorsal- $(D)$, anal- $(A)$, pectoral- $(P)$, and ventral $(V)$ fins (two last branched dorsal and anal fin rays were counted as one); number of scales in the lateral line (l.l.), number of scales between lateral line and dorsal fin base (ss), number of scales between lateral line and ventral fin base $(i)$, number of pharyngeal teeth $(P h F)$; number of vertebrae in different portions of the vertebral column: predorsal vertebrae $(V p d)$ (i.e., lying anteriorly from dorsal fin insertion), abdominal vertebrae $(V a)$, intermediate vertebrae $(V i)$, caudal vertebrae $(V c)$, hemal vertebrae $(V h)$ (caudal- plus intermediate ones with parapophyses connected by a bridge below the hemal canal); total number of vertebrae $(V t)$; the number of openings of cephalic sensory canals on particular bones in the neurocranium and visceral skeleton: preoperculomandibular canal (CPM) (dentary, articular, preoperculum, operculum); supraorbital canal (CSO) (nasal, frontal); supratemporal canal (CST) (parietal, posttemporal); infraorbital canal (CIO) (lacrimal, pterotic). Internal features were counted from dry skeleton preparations made by boiling in hot water. Pore counts were made from both the left and right side of the head; the number of canal openings of an individual bone included entry and exit.

On the skull, 20 bone measurements were taken: ethmoid region depth on the level of the posterior margin of supraethmoid ( $H$ eth), neurocranium depth on the level of the supraoccipital ( $H S O c)$, neurocranium depth on the level of the parasphenoid ( $H p s)$, length of neurocranial base without pharyngeal process (L.bas.n.), cranial roof length (L.cr.r.), ethmoid length ( $L$ eth), neurocranium width between lateral margins of lateral ethmoids (Lt eth), 
neurocranium width between lateral margins of sphenotic lateral processes ( $L t s p h o)$, neurocranium width between lateral margins of pterotics on the level of the posterior pterotic process base ( $L t$ pto), masticatory plate length (Lt mas $p l$ ), lacrimal bone length $(L$ iol), opercular bone height $(H o)$, opercular bone width $(L)$, interopercular bone width (L1), subopercular bone width (L2), hyomandibular bone height ( $H$ hyo $)$, palatine bone length ( $L$ pal), dentary bone length $(L$ dent), premaxilla bone length $(L p m x)$, maxilla bone length $(L m x)$. These measurements were expressed as a percentage of the cranial base length (L.bas.n.) (Bogutskaya 1994). In order to estimate the degree of "wideness" or "narrowness of crania the ratio Lt pto to cranial roof length L.cr.r. was counted.

All the data were statistically processed, involving means $(\bar{x})$, standard deviations $(s)$, and coefficient of variation $(\mathrm{CV}, \%)$.

\section{RESULTS}

Biometric features. The range of body length SL of analysed fish was $87.40-116.10 \mathrm{~mm}, 101.12 \mathrm{~mm}$ on aver- age. The lateral head length $(l c)$ ranged from $21.20-30.50$ $\mathrm{mm}, 25.08 \mathrm{~mm}$ on average.

Relative values of biometric features in gudgeon are given in Table 1. Analysed biometric features were characterised by the coefficient of variation ranged from $3.35 \%$ to $14.69 \%$.

The head is comparatively short. Mouth inferior with a pair of maxillary barbels.

The body is low and elongate. The caudal peduncle is considerably long, comprising $16.55 \%-26.30 \%$ of SL. It is laterally compressed with depth much greater than width.

The dorsal fin is high with outer edge concave. Its base is short.

External meristic features. The results are given in Table 2. In the dorsal fin $78 \%$ of the fish had 8 soft rays.

The gudgeon has short anal fin. More than half $(55.6 \%)$ of the analysed fish had 7 rays. Its outer margin is slightly convex or almost straight.

The number of soft rays in the pectoral fin ranges from 11 to 15 , with 12 and 13 being the most common results, found in $41.4 \%$ and $44.8 \%$ of the fish, respectively. The

Relative values of biometric characters of gudgeon, Gobio gobio from the Odra River drainage

\begin{tabular}{|c|c|c|c|c|}
\hline Character & Range & $\bar{x}$ & $s$ & $\mathrm{CV}[\%]$ \\
\hline \multicolumn{5}{|c|}{ in \% of body length (SL) } \\
\hline Head length $l c$ & $22.6-26.8$ & 24.8 & 1.06 & 4.28 \\
\hline Predorsal distance $p D$ & $43.6-51.6$ & 47.7 & 1.60 & 3.35 \\
\hline Postdorsal distance $p o D$ & $35.3-47.2$ & 41.1 & 3.01 & 7.33 \\
\hline Maximum body depth $H$ & $16.8-23.4$ & 20.3 & 1.90 & 9.37 \\
\hline Preanal distance $p A$ & $52.5-70.5$ & 61.6 & 4.16 & 6.75 \\
\hline Minimum body depth $h$ & $6.4-10.6$ & 8.4 & 1.03 & 12.33 \\
\hline Caudal peduncle length $l p c$ & $16.6-26.3$ & 19.9 & 2.22 & 11.17 \\
\hline Pectoral fin length $l P$ & $13.2-23.0$ & 18.8 & 2.07 & 11.01 \\
\hline Ventral fin length $l V$ & $13.4-19.6$ & 16.5 & 1.28 & 7.75 \\
\hline Dorsal fin height $h D$ & $17.3-25.76$ & 21.6 & 1.84 & 8.53 \\
\hline Anal fin height $h A$ & $12.5-18.8$ & 21.6 & 1.47 & 6.81 \\
\hline Dorsal fin length $l D$ & $8.8-14.7$ & 12.5 & 1.19 & 9.51 \\
\hline Anal fin length $l A$ & $5.7-9.8$ & 7.5 & 0.99 & 13.23 \\
\hline $\mathrm{P}-\mathrm{V}$ distance & $22.6-32.5$ & 26.6 & 2.40 & 9.04 \\
\hline $\mathrm{V}-\mathrm{A}$ distance & $18.2-28.1$ & 21.7 & 2.15 & 9.92 \\
\hline \multicolumn{5}{|c|}{ in $\%$ of head length $(l c)$} \\
\hline Preorbital distance $\mathrm{prO}$ & $34.7-49.4$ & 42.0 & 3.45 & 8.21 \\
\hline Eye diameter $O$ & $12.1-25.0$ & 18.6 & 2.73 & 14.69 \\
\hline Postorbital distance $p o O$ & $34.0-47.8$ & 40.0 & 3.23 & 8.07 \\
\hline Head depth $h c$ & $48.1-63.3$ & 54.0 & 3.40 & 6.30 \\
\hline Head width $l a c$ & $38.4-50.5$ & 45.0 & 2.71 & 6.03 \\
\hline Lower jaw length $\operatorname{lm} d$ & $18.0-30.7$ & 22.4 & 2.78 & 12.40 \\
\hline Barbel length $l b$ & $14.4-28.0$ & 22.0 & 3.89 & 17.72 \\
\hline
\end{tabular}

$\bar{x}$, mean; $s$, standard deviation; $\mathrm{CV}$, coefficient of variation. 
Table 2

Values of external meristic characters of gudgeon, Gobio gobio, from the Odra River drainage

\begin{tabular}{|c|c|c|c|c|}
\hline Feature & Range & $\bar{x}$ & $s$ & $\mathrm{CV}[\%]$ \\
\hline Number of soft rays in dorsal fin $D$ & $7-9$ & 8.0 & 0.23 & 2.99 \\
\hline Number of soft rays in anal fin $A$ & $6-7$ & 6.7 & 0.47 & 6.98 \\
\hline Number of soft rays in pectoral fin $P 1$ & $11-15$ & 12.5 & 0.81 & 6.46 \\
\hline Number of soft rays in pectoral fin $P 2$ & $11-15$ & 12.7 & 0.83 & 6.56 \\
\hline Number of soft rays in pectoral fin $P$ & $11-15$ & 12.6 & 0.72 & 5.69 \\
\hline Number of soft rays in ventral fin $V 1$ & $7-8$ & 7.1 & 0.25 & 3.48 \\
\hline Number of soft rays in ventral fin $V 2$ & $6-8$ & 7.0 & 0.25 & 3.63 \\
\hline Number of soft rays in ventral fin $V$ & $6.5-7.5$ & 7.0 & 0.18 & 2.60 \\
\hline Number of scales in the lateral line l.l.1 & $37-41$ & 39.3 & 0.91 & 2.33 \\
\hline Number of scales in the lateral line l.l.2 & $38-41$ & 39.2 & 0.76 & 1.94 \\
\hline $\begin{array}{l}\text { Number of scales in the lateral line } l . l \text {. } \\
\text { Number of scales between lateral line and dorsal }\end{array}$ & $38-40.4$ & 39.3 & 0.63 & 1.60 \\
\hline fin base $s s$ & $5-6$ & 5.9 & 0.39 & 6.60 \\
\hline $\begin{array}{l}\text { Number of scales between lateral line and ventral } \\
\text { fin base } i\end{array}$ & 5 & 5.0 & 0.00 & 0 \\
\hline
\end{tabular}

$\bar{x}$, mean; $s$, standard deviation; CV, coefficient of variation; numbers 1 and 2 denote left and right side of the body.

gudgeon has 7 soft rays in the ventral fin (58\% of the fish).

The lateral line is complete.

Internal meristic features. The gudgeon has two rows of pharyngeal teeth. In $58.1 \%$ of the fish the pattern is $3.5-5.3$, and in $25.8 \%$ of them $2.5-5.2$. The teeth in the internal row are fine. In the second, main row they are bigger and more massive. All teeth are cylindrical with pointed, hooked tips and reduced grinding surface.

The total number of vertebrae ranges from 38 to 41 (Table 3). In $36 \%$ of the fish 39 vertebrae were found, whilst in $33 \%$ of fish the vertebral number reached 40 . The analysis of the number of vertebrae in different regions of the vertebral column demonstrates that the lowest coefficient of variation, $\mathrm{CV}=2.13 \%$ is found in the case of the total number of vertebrae, whilst the highest, $\mathrm{CV}=$ $12.64 \%$, is found for predorsal vertebrae number (Table 3 ).

The number of pores on the bones of the skull is given in Table 4. The preoperculo-mandibular canal (CPM) most commonly has $15-20$ pores. The preoperculum has the most numerous pores. All the examined specimens had 2 pores on the operculum. In the supraorbital canal (CSO) there are 8-11 pores. This canal does not extend onto the parietal bone. The infraorbital canal (CIO) passes through 5 interorbital bones (Fig. 2) and the pterotic bone. On the first infraorbital bone, the lacrimal, most of the fishes analysed show 6 pores $(66 \%)$, its number ranges from 5 to 8 . The pterotic bone has, most often, 4 or 5 pores.

Osteological description. The neurocranium (Fig. 2) is low and moderately broad. Proportions of the neurocranium (\% L.bas.n.) are shown in Table 5. The ratio of $L t$ pto to cranial roof length L.cr.r. ranges within $44.14-56.72$, assuming 50.13 on average. This means that the skull of gudgeon is rather slender and narrow. The cranial roof is formed by two paired bones, the frontals and the parietals. The lateral concavities of both frontals are

Number of vertebrae of gudgeon, Gobio gobio, from the Odra River drainage

\begin{tabular}{lcccc}
\hline Feature & $\bar{x}$ & Range & $s$ & CV $(\%)$ \\
\hline Predorsal vertebrae $V p d$ & 7.8 & $6-9$ & 0.98 & 12.64 \\
Abdominal vertebrae $V a$ & 11.5 & $10-13$ & 0.91 & 7.93 \\
Intermediate vertebrae $V i$ & 4.5 & $4-5$ & 0.51 & 11.33 \\
Abdominal and intermediate vertebrae $V a i$ & 16.0 & $14-17$ & 0.86 & 5.38 \\
Caudal vertebrae $V c$ & 16.4 & $15-18$ & 0.76 & 4.62 \\
Hemal vertebrae $V h$ & 17.5 & $16-19$ & 0.91 & 5.21 \\
Total vertebrae $V t$ & 39.4 & $38-41$ & 0.84 & 2.13 \\
\hline
\end{tabular}

$\bar{x}$, mean; $s$, standard deviation; $\mathrm{CV}$, coefficient of variation. 
Table 4

Number of pores in selected bones of lateral-system canals of gudgeon, Gobio gobio, from the Odra River drainage

\begin{tabular}{|c|c|c|c|c|c|}
\hline Canal & Bone & Range & $\bar{x}$ & $s$ & $\mathrm{CV}[\%]$ \\
\hline \multirow{12}{*}{ 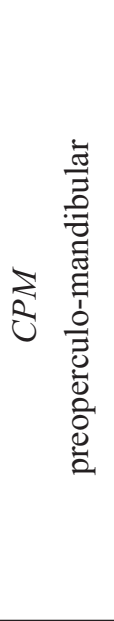 } & d-dentary & $4-5$ & 4.1 & 0.34 & 8.25 \\
\hline & $\mathrm{d} 1$ & $4-5$ & 4.1 & 0.34 & 8.25 \\
\hline & $\mathrm{d} 2$ & $4-5$ & 4.1 & 0.34 & 8.25 \\
\hline & a-articular & $1-3.5$ & 3.0 & 1.12 & 37.33 \\
\hline & a1 & $2-3$ & 2.8 & 0.42 & 15.11 \\
\hline & a2 & $2-3$ & 2.8 & 0.37 & 13.03 \\
\hline & p-preoperculum & $7.5-9.5$ & 8.5 & 0.51 & 6.00 \\
\hline & $\mathrm{p} 1$ & $7-10$ & 8.6 & 0.76 & 8.85 \\
\hline & $\mathrm{p} 2$ & $7-9$ & 8.4 & 0.61 & 7.25 \\
\hline & o-operculum & 2 & 2 & 0 & 0 \\
\hline & o1 & 2 & 2 & 0 & 0 \\
\hline & o2 & 2 & 2 & 0 & 0 \\
\hline \multirow{6}{*}{ 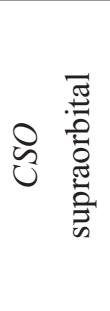 } & n-nasal & $3-3.5$ & 3.3 & 0.35 & 10.77 \\
\hline & $\mathrm{n} 1$ & $3-4$ & 3.5 & 0.52 & 15.07 \\
\hline & $\mathrm{n} 2$ & 3 & 3 & 0 & 0 \\
\hline & f-frontal & $5-6.5$ & 5.9 & 0.42 & 7.12 \\
\hline & f1 & $5-7$ & 6.0 & 0.52 & 8.67 \\
\hline & $\mathrm{f} 2$ & $5-7$ & 5.8 & 0.55 & 9.48 \\
\hline \multirow{6}{*}{ 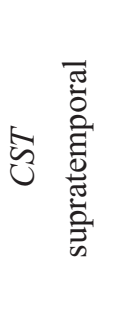 } & p-parietal & $2.5-4$ & 3.1 & 0.47 & 15.02 \\
\hline & $\mathrm{p} 1$ & $2-4$ & 3.1 & 0.55 & 17.74 \\
\hline & $\mathrm{p} 2$ & $2-4$ & 3.2 & 0.59 & 18.61 \\
\hline & pt-posttemporal & $2-2.5$ & 2.0 & 0.12 & 5.91 \\
\hline & $\mathrm{pt1}$ & $2-3$ & 2.0 & 0.18 & 8.87 \\
\hline & $\mathrm{pt} 2$ & $2-3$ & 2.0 & 0.18 & 8.87 \\
\hline \multirow{6}{*}{ 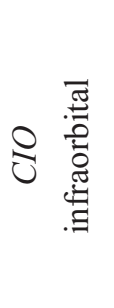 } & 1-lacrimal & $5-7$ & 6.1 & 0.45 & 7.43 \\
\hline & 11 & $5-7$ & 6.0 & 0.59 & 9.88 \\
\hline & 12 & $5-8$ & 6.2 & 0.68 & 11.04 \\
\hline & p-pterotic & $3.5-5.5$ & 4.8 & 0.44 & 9.22 \\
\hline & $\mathrm{p} 1$ & $3-6$ & 4.7 & 0.61 & 13.12 \\
\hline & $\mathrm{p} 2$ & $4-6$ & 4.8 & 0.47 & 9.73 \\
\hline
\end{tabular}

$\bar{x}$, mean; $s$, standard deviation; CV, coefficient of variation; numbers 1 and 2 denote left and right side of the body.

deep so the minimum width of the bone is approximately half of the greatest width.

The supraethmoid is short and broad; its average length is $19.53 \%$ of L.bas.n. The medial anterior notch is shallow. The posterior margin of the supraethmoid is firmly connected with the frontals only in the corners forming small gape in the middle (Fig. 2). The depth of mesethmoid determines the entire depth of the ethmoid region, which is comparatively low. The lateral ethmoid contains the entire olfactory foramen. The vomer is short but wide. The interorbital septum is formed by the orbitosphenoid. The pterosphenoid is elongate and is longer than the orbitosphenoid.
The posterior pterotic process is long, pointed, and directed caudally. The supraoccipital crest is low, weekly pronounced. The pharyngeal process has a masticatory plate, which is pentagonal in shape. Its mean width is $10.87 \%$ L.bas.n.

Gudgeon has five infraorbitals (Fig. 3). The first, lacrimal and the third are the longest. The lacrimal length in the sample is $36.54 \%$ L.bas.n. The supraorbital is distinct and well formed.

The premaxilla and maxilla are elongate. The premaxilla has a short median process. The anterior portion of the dentary is rather narrow and elongated. Its coronoid process is almost vertical (Fig. 4). The lower jaw is relatively short, only 


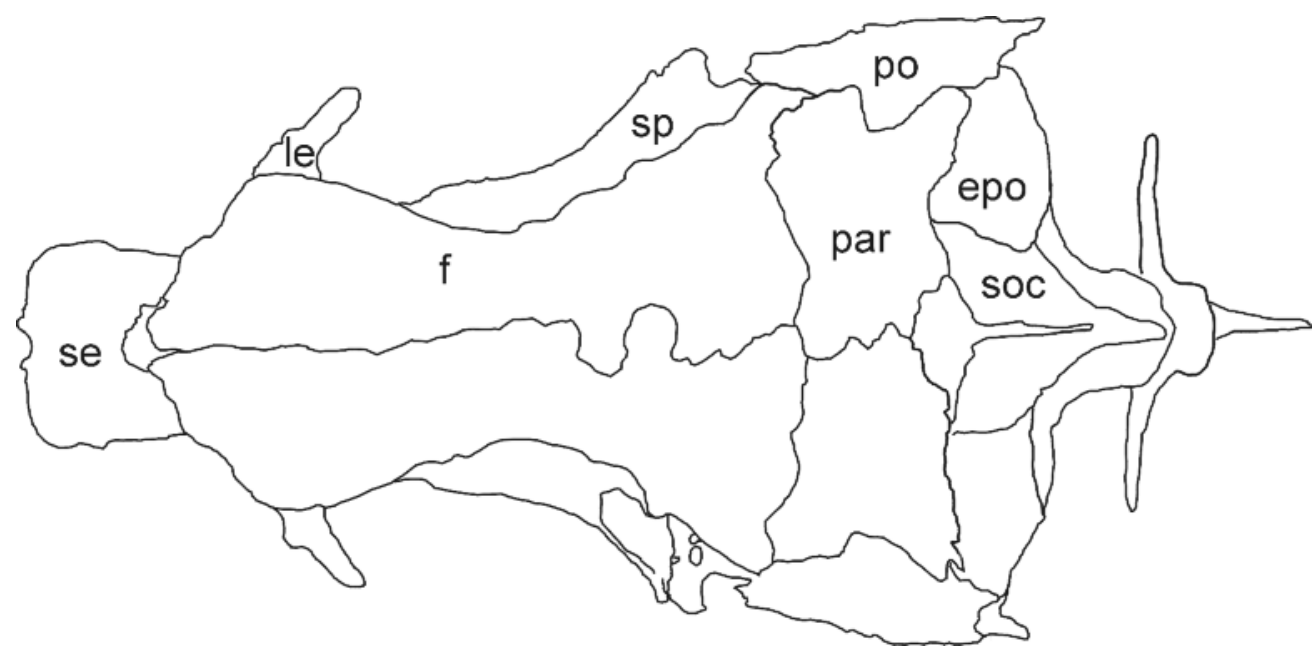

Fig. 2. The neurocranium and dermal skull roof of gudgeon, Gobio gobio, from the Odra River drainage (95.7 mm in SL), dorsal view; abbreviations: epo, epiotic; f, frontal; le, lateral ethmoid; par, parietal; po, pterotic; se, supaethmoid; soc, supraoccipital; sp, spenotic

Table 5

Skull and bone measurements of gudgeon, Gobio gobio, from the Odra River drainage

\begin{tabular}{|c|c|c|c|c|}
\hline Feature & Range & $\bar{x}$ & $s$ & $\mathrm{CV}[\%]$ \\
\hline \multicolumn{5}{|l|}{ [in $\mathrm{mm}]$} \\
\hline Length of neurocranial base without pharyngeal process L.bas.n. & $19.5-25.9$ & 23.0 & & \\
\hline \multicolumn{5}{|c|}{ [in \% of the neurocranium length, L.bas.n.] } \\
\hline \multirow{6}{*}{$\begin{array}{l}\text { Ethmoid region depth } H \text { eth } \\
\text { Neurocranium depth on the supra } \\
\text { Neurocranium depth on the paras } \\
\text { Cranial roof length L.cr.r. } \\
\text { Ethmoid length } L \text { eth }\end{array}$} & $13.1-21.0$ & 17.3 & 1.92 & 11.07 \\
\hline & $24.5-31.9$ & 27.7 & 1.74 & 6.29 \\
\hline & $23.4-29.0$ & 26.1 & 1.48 & 5.68 \\
\hline & $82.6-95.8$ & 90.4 & 3.03 & 3.35 \\
\hline & $15.9-24.0$ & 19.5 & 2.20 & 11.26 \\
\hline & 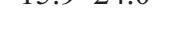 & & & \\
\hline \multirow{2}{*}{$\begin{array}{l}\text { Neurocranium width between lateral margins of lateral ethmoids Lt eth } \\
\text { Neurocranium width between sphenotics Lt spho }\end{array}$} & $31.9-46.4$ & 43.3 & 2.71 & 6.23 \\
\hline & $41.6-52.1$ & 46.0 & 2.19 & 4.76 \\
\hline Neurocranium width between pterotics Lt pto & $44.1-56.7$ & 50.2 & 2.48 & 4.95 \\
\hline Masticatory plate length $L t$ mas $\mathrm{pl}$ & $8.6-12.9$ & 10.9 & 0.93 & 8.55 \\
\hline Lacrimal bone length $L$ iol & $30.0-45.6$ & 36.5 & 3.49 & 9.55 \\
\hline Hyomandibular bone height $H$ & $33.6-47.2$ & 39.0 & 3.61 & 9.27 \\
\hline Opercular bone width $L$ & $29.1-50.3$ & 38.6 & 5.86 & 15.18 \\
\hline Interopercular bone width $L 1$ & $31.7-52.3$ & 39.6 & 3.82 & 9.65 \\
\hline Subopercular bone width $L 2$ & $41.0-53.8$ & 47.4 & 3.11 & 6.57 \\
\hline Hyomandibular bone height $H$ hyo & 33.- -44.481 & 39.0 & 2.85 & 7.30 \\
\hline Palatine bone length $L$ pal & $24.5-38.5$ & 31.3 & 2.93 & 9.37 \\
\hline Dentar bone length $L$ dent & $\begin{array}{l}24.5-50.5 \\
326-431\end{array}$ & 31.3 & 281 & 7.51 \\
\hline Premaxilla bone length $L p m x$ & 1 & 0 & 1 & 1.40 \\
\hline \multirow{2}{*}{ Maxilla bone length $\operatorname{Lmx}$} & $22.8-32.3$ & 28.0 & 2.34 & 8.36 \\
\hline & $26.1-37.0$ & 31.3 & 2.57 & 8.21 \\
\hline
\end{tabular}

$\bar{x}$, mean; s, standard deviation; $\mathrm{CV}$, coefficient of variation. 


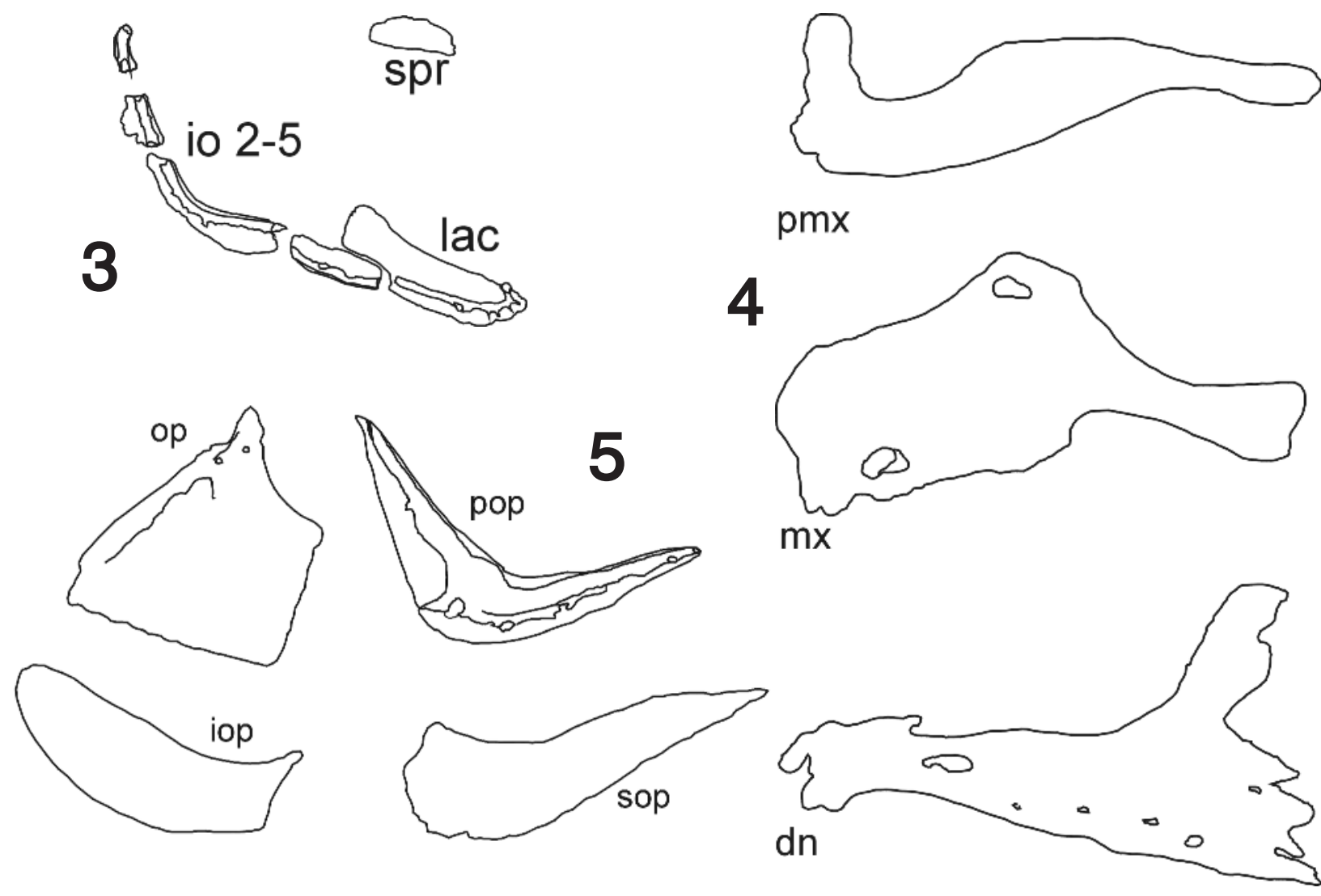

Figs. 3-5. Bones of the viscerocranium and circumorbital series of gudgeon, Gobio gobio, from the Odra River drainage (95.7 $\mathrm{mm}$ in SL) Fig. 3. Infraorbitals (io 2-5, infraorbitals 2-5; lac, lacrimal; spr, supraorbitale) Fig. 4. Jaws (pmx, premaxilla; mx, maxilla; dn, dentary) Fig. 5. Opercular series (iop, interoperculum; op, operculum; pop, praeoperculum; sop, suboperculum)

46.02\% L.bas.n. on average. The opercular series (Fig. 5) consists of four bones. The operculum is the largest of the series and has an articular process towards the hyomandibula.

\section{DISCUSSION}

The species that belong to the genus Gobio are morphologically similar to each other, and this has led to misidentifications for many years (Freyhof et al. 2000). In particular, the G. gobio complex is a taxonomically difficult species, which shows an extraordinary phenotypic diversity, but the validity of many of its nominal species is still controversial (Bănărescu et al. 1999, Schreiber 2000). The common gudgeon is one of the most variable fish species in Europe. Two morphotypes were distinguished: lotic (rheophilic) and lentic (limnophilic). They differ in colour, some biometric features (Bănărescu et al. 1999), and in some meristic features, especially the number of scales in the lateral line (Kux and Libosvarsky 1981).

Bănărescu (1954) has made an extensive taxonomic study of the genus Gobio in Romanian waters. According to the results for Gobio gobio five morphometric characters were chosen: length of barbels, eye diameters, maximum and minimum body depth, and caudal peduncle length. The rheophilus form, inhabiting upper reaches of rivers, showed lower maximum and minimum body depth, smaller head and eye diameter but longer barbels, and caudal peduncle than the limnophilus form. The same five characters were chosen by Libosvarsky and Kux (1982). Kux and Libosvarsky (1981) used four of them (without the caudal peduncle length) and the number of scales in the lateral line.

Rolik (1965) tried to classify several populations from Vistula drainage into lotic and lentic forms and consider to be lotic form of G. gobio gobio (cf. Nowak et al. 2006). The present authors' data and other populations studied by Jarzynowa and Rechulicz (1997), Nowak et al. (2008) were riverine, so the differences could not be explained in terms of these ecological forms.

The type locality of the species is England. The English populations of G. gobio gobio, both reophilic and limnophilic, are characterized by longer heads, averaging 27.3, 28.5, and 28.1\% SL for different groups (Bănărescu et al. 1999).

Kottelat and Persat (2005) criticised this classification as inconsistent and insufficiently defined (Nowak et al. 2006).

Bănărescu (1954) has stated that the eye diameter $(O)$ was a good parameter in discriminating between $G$. gobio and its congeners. The eye diameters and head length of gudgeons from the Elbe and the Odra River systems are 
more similar to those of specimens from the Danube. Gudgeons from the Vistula system are more similar to the English ones (Rolik 1965). The eye diameter in the analysed specimens varies from $12.1 \%$ to $25.0 \%$ of head length $l c$ and is characterized by high coefficient of variation $(\mathrm{CV}=14.7 \%)$, while in another Polish sample the range is $18.8 \%-25.7 \%$ lc (Nowak et al. 2008). Vasil'eva et al. (2005) demonstrated the great morphological similarity between the Crimean gudgeons with certain Bulgarian populations. The eyes of these gudgeon were very small. It is necessary to take into consideration that this feature is subject to the size variability (Bănărescu et al. 1999, Vasil'eva et al. 2005) and implies a comparison of specimens only of similar size.

Other characters used in comparisons by different authors are head length, snout length and postorbital distance (Rolik 1965, Skóra and Włodek 1966, Nowak et al. 2008). According to them gudgeons in the Vistula River drainage visually differed from these in the Odra River drainage in shorter head, a bit longer snout and deeper body. Specimens from the Bukowa River (Jarzynowa and Rechulicz 1997) were characterized by long head $(25.0 \%-30.4 \% \mathrm{SL})$. They are more similar to those from Soła River (Skóra and Włodek 1966) compare to the San River (Rolik 1965).

The meristic characters although, having a taxonomic importance are not stable and are characterized by certain variability, which is likely to be characteristic for a given population or species. In the analysed sample the principal merisitc features are as follows: $D$ III 7-9; $A$ III 6-7; $P$ I 11-15; $V$ I 6-8; l.l. 37-41. According to Skóra and Włodek (1971), who analysed samples from the rivers of southern Poland, those meristic features that show a small variability are extremely good diagnostic features. In their study, these were the number of scales on the lateral line of the body and the number of vertebrae $(\mathrm{CV}=2.96 \%$ and $2.92 \%$, respectively). The sample under study showed the lowest variability for the same features, $1.60 \%$ for the number of scales and $2.13 \%$ for the total number of vertebrae. There is geographical variation in the number of scales in the lateral line. This character is more or less uniform over large areas. The English populations are characterized by the range $41-44$, the fishes in various tributaries of the Vistula River have 39-44 scales, in the Danube Basin 36-44 scales, and the specimens from Crimea (Alma and Salgir Rivers) have 37-42 scales (Bănărescu et al. 1999). Other data on meristic characters, available in literature, are given in Table 6.

The pharyngeal teeth in the subfamily Gobioninae show considerable variation both in their morphology and number (Ramaswami 1955). There are three major morphotypes, three-rows, two-rows, and one-row. Hemibarbus is the only genus with three-rows of pharyngeal teeth. Squalidus, Gobio, Mesogobio, and Gobiobotia typically have two-rowed pharyngeal teeth of 3.5-5.3 formula (Hosoya 1986). In the analysed sample all specimens had the formula $3.5-5.3$ and 2.5-5.2. There are descriptions of $G$. gobio with the following formulas:
3.5-5.3 and 2.5-5.2 (Ramaswami 1955), 3.5-5.2, 2.5-5.3, 2.4-5.3, 3.5-5.4, as well as 1.5-5.1 (Gąsowska 1962, Rolik 1965, Białokoz 2000).

With a limited number of suitable external meristic features, it is favourable to increase their number and take into account some elements of the internal skeleton. Most of the earlier studies on the Gobioninae are mainly based on the traditional external characters (Naseka 1996). The first who (in 1938) declared the need of studying anatomical characters besides external features was Taranetz (Naseka 1998). Hosoya (1986) analysed phylogenetic relationships of the subfamily Gobioninae after a deep study of its osteology and sensory canal structure.

The total number of vertebrae in gobionins ranges between 36 and 55. The number of abdominal vertebrae is larger than, about equal to or smaller than that of caudal ones (Naseka 1996). In the analysed sample of gudgeon the total number of vertebrae ranged from 38-41, on average 39.44. The same range was given by Skóra and Włodek $(1966,1971)$ for the fish from the Soła River. The other vertebral counts were as follows: 35-40 (Gąsowska 1962, Rolik 1965, Białokoz 2000) and 35-38 (Rolik 1967). Naseka (1996) who studied a sample of 245 specimens of gudgeon gave the following values of vertebrae numbers: total 37-43, most commonly 39 and $40(31 \%$ and $35 \%$ of fish respectively), abdominal 19-24, with the most common number 21 (56\%). This number included the Weberian- and intermediate ones. The caudal region was characterized by 17 to 21 with a modal of $19(47 \%)$ vertebrae. Usually, the number of vertebrae in different regions is not provided by other authors. In the sample of gudgeon examined within the presently reported study, the same range of the abdominal vertebrae amounted to 18-22, whilst in the caudal region 15-18.

In 1946 Tretyakov was the first to use the features of the cephalic lateral line system for understanding cyprinid phylogeny (Hensel 1978). The general pattern in the Gobionine is that the infraorbital canal connects the supraorbital- (CSO), the preoperculio-mandibular- (CPM), and the supratemporal- (CST) canals (Hosoya 1986). All of the cephalic canals are complete (Bănărescu et al. 1999). In the Gobio species the supraorbital canal (CSO) run only through nasal and frontal bones. On the frontal it is divided into two branches. Rarely, this canal extends onto the parietal bone. There is no information's about pore numbers for Polish populations. The CIO has greater number of pores than $G$. albipinnatus, designated by the formula (15-17) 18, 19 (20, 21) (Bănărescu et al. 1999). Specimens from the present study had 16-19 pores. Vasil'eva et al. (2005) gave some data about the number of pores on particular elements of the skull in "short-barbeled Crimean gudgeon, Gobio krymensis"- until recently regarded a junior synonym of Gobio gobio gobio by Kottelat (1997) and Froese and Pauly (2008). These results are very similar to the common gudgeon, G. gobio. In the majority of specimens of the "Crimean gudgeon" on the frontal bone in most specimens is eight pores (in the common gudgeon, seven), on pterotic three-fives pores (in the common gud- 
Table 6

Comparison of selected meristic character of gudgeon, Gobio gobio, with the data from the literature (mean value in brackets)

\begin{tabular}{|c|c|c|c|c|c|c|c|c|}
\hline \multirow[t]{2}{*}{ Water body } & \multirow[b]{2}{*}{$D$} & \multirow[b]{2}{*}{$A$} & \multirow[b]{2}{*}{$P$} & \multirow[b]{2}{*}{$V$} & \multirow[t]{2}{*}{$V t$} & \multirow[t]{2}{*}{ l.l. } & \multirow[t]{2}{*}{ ss } & \multirow[t]{2}{*}{$i$} \\
\hline & & & & & & & & \\
\hline Odra River drainage (present study) & $\begin{array}{l}7-9 \\
(8)\end{array}$ & $\begin{array}{c}6-7 \\
(6.7)\end{array}$ & $\begin{array}{l}11-15 \\
(12.6)\end{array}$ & $\begin{array}{l}6-8 \\
(7)\end{array}$ & $\begin{array}{l}38-41 \\
(39.4)\end{array}$ & $\begin{array}{l}37-41 \\
(39.2)\end{array}$ & $\begin{array}{c}5-6 \\
(5.9)\end{array}$ & 5 \\
\hline Wieprz River drainage (Danilkiewicz 1997) & 7 & 6 & $\begin{array}{l}12-17 \\
(14.9)\end{array}$ & 7 & - & $\begin{array}{c}39-44 \\
(41.80)\end{array}$ & $\begin{array}{l}5-6.5 \\
(5.79)\end{array}$ & $\begin{array}{l}4-6.5 \\
(4.8)\end{array}$ \\
\hline Soła (Skóra and Włodek 1966, 1971) & 7 & $5-6$ & - & - & $\begin{array}{l}38-41 \\
(39.6)\end{array}$ & $39-45$ & $5-6$ & $3-4$ \\
\hline Strwiąż (Rolik 1967) & 7 & $\begin{array}{l}5-7 \\
(6)\end{array}$ & - & - & $35-38$ & $39-44$ & $5-6$ & $3-4$ \\
\hline Berg (1949) & 7 & 6 & & & & $40-45$ & $5-6$ & $3-4$ \\
\hline Bănărescu (1962) & - & - & - & - & - & $41-44$ & - & - \\
\hline Kux and Libovarsky (1981) & - & - & - & - & - & $40-45$ & - & - \\
\hline Rudawa River (Nowak et al. 2008) & $\begin{array}{c}7 \\
(7.0)\end{array}$ & $\begin{array}{c}5-6 \\
(6.0)\end{array}$ & - & - & - & $\begin{array}{l}38-44 \\
(40.8)\end{array}$ & $\begin{array}{l}5-6 \\
(5.8)\end{array}$ & $\begin{array}{l}3-4 \\
(3.9)\end{array}$ \\
\hline Silnica River (Nowak et al. 2008) & $\begin{array}{c}7 \\
(7.0)\end{array}$ & $\begin{array}{c}5-6 \\
(6.0)\end{array}$ & - & - & - & $\begin{array}{l}38-42 \\
(40.5)\end{array}$ & $\begin{array}{c}5-6 \\
(5.9)\end{array}$ & $\begin{array}{l}4-5 \\
(4.1)\end{array}$ \\
\hline
\end{tabular}

$\mathrm{D}, \mathrm{A}, \mathrm{P}, \mathrm{V}=$ soft (branched) fin ray numbers of dorsal-, anal-, pectoral- and ventral fins, respectively; $V t=$ total number of vertebrae; 1.1. = number of scales in the lateral line; $\mathrm{ss}=$ number of scales between lateral line and dorsal fin base; $\mathrm{i}=$ number of scales between lateral line and ventral fin base.

geon usually there are five pores), on praeoperclum the number of pores varies from seven to eleven (in the common gudgeon, seven-eight).

Some elements of the head anatomy were described by Vandewalle (1974), Hosoya (1986), Bănărescu et al. (1999), and Vasil'eva et al. (2004).

All the genera of Gobioninae, including the analysed specimens of gudgeon, have a pair of supraorbital bones. The infraorbital series is composed of the lacrimal and succeeding bones. Hosoya (1986) divided the series into two morphotypes. Gobio belongs to the first morphotype characterized by the infraorbital canal running backward along the ventral margin of the lacrimal. This morphotype can be also observed in Hemibarbus, Squalidus, and Mesogobio.

The general appearance of the neurocranium, including bone measurements, is described in details for G. albipinnatus, widely distributed and abundant species that was formerly confused with its congeners, especially G. gobio (cf. Bănărescu et al. 1999). The skull depth in the ethmoid region of G. gobio is similar to G. albipinnatus, being on average $13.1 \%-21 \%$ and $15.7 \%-20.0 \%$, $17.3 \%$, and $17.5 \%$ L.bas.n., respectively. In the sphenotic region, the range is $23.4 \%-29.0 \%$ L.bas.n. for G. gobio and $24.3 \%-29.6 \%$ L.bas.n. for G. albipinnatus. The depth of the occipital part is $24.5 \%-31.9 \%$ L.bas.n. and $25.2 \%-30.5 \%$ L.bas.n., respectively. The width of the neurocranium of $G$. albipinnatus, between the lateral margins of the lateral ethmoids, is $38.6 \%$ to $44.8 \%$ L.bas.n., that between the margins of the sphenotics ranges from $42.9 \%$ to $52.3 \%$, and between the lateral margins of the pterotics varies from $50.0 \%$ to $57.3 \%$ of L.bas.n. These values for analysed sample of $G$. gobio are as follows: $31.9 \%-46.4 \%, 41.6 \%-52.1 \%$, and $44.1 \%-56.7 \%$ of L.bas.n. These figures indicate that the neurocranium of G. albipinnatus is a little deeper and wider than that of G. gobio. According to Vasil'eva et al. (2004) the skull depth of G. gobio (\% L.bas.n.) are as follows: H eth 17.1\%-20.1\%, $H$ soc $27.0 \%-28.9 \%$, and $H$ ps $24.9 \%-28.1 \%$. These measurements were made for the first time for a Polish sample.

Although knowledge on how to distinguish between Gobio species has improved in recent years (Bănărescu et al. 1999, Vasil'eva et al. 2004, 2005), their identification is still not easy because of extraordinary phenotypic diversity. There is still too little comparative material available for Polish populations.

\section{ACKNOWLEDGMENT}

The study was supported by grant No. 0208.805 from the University of Warmia and Mazury in Olsztyn, Poland.

\section{REFERENCES}

Bănărescu P.M. 1954. Biometrische und systematische Studien an Gobio gobio aus Rumänien. Věstník Československé Společnosti Zoologické 18: 6-40.

Bănărescu P.M. 1992. A critical updated checklist of Gobioninae (Pisces, Cyprinidae). Travaux du Muséum 
National d'Histoire Naturelle "Grigore Antipa" 32: 305-330.

Bănărescu P.M. 1999. Gobio Cuvier, 1816. Pp. 33-36. In: Bănărescu P.M. (ed.) The freshwater fishes of Europe. Cyprinidae 2. Part I: Rhodeus to Capoeta. AULA Verlag, Wiebelsheim.

Bănărescu P.M., Šorić V.M., Economidis P.S. 1999. Gobio gobio (Linnaeus, 1758). Pp. 81-134. In: Bănărescu P.M. (ed.) The freshwater fishes of Europe. Cyprinidae 2. Part I: Rhodeus to Capoeta. AULA Verlag, Wiebelsheim.

Berg L.S. 1949. Ryby presnyh vod SSSR i sopredel'nyh stran. [Freshwater fishes of the USSR and neighbouring states.] Izdatel'stvo Akademii Nauk

SSSR, Moskva-Leningrad. [In Russian].

Białokoz W. 2000. Kiełb (kiełb krótkowąsy) Gobio (Gobio) gobio (Linnaeus, 1758). [Gudgeon, Gobio (Gobio) gobio (Linnaeus, 1758).] Pp. 220-223. In: Brylińska M. (ed.) Ryby słodkowodne Polski. [The freshwater fishes of Poland.] PWN, Warszawa. [In Polish.]

Bogutskaya N.G. 1994. A description of Leuciscus lepidus (Heckel, 1843) with comments on Leuciscus and leuciscine-aspinine relationships (Pisces, Cyprinidae). Annalen des Naturhistorischen Museums in Wien B 96: 599-620.

Callejas C., Lusková V., Ochando M.D. 2004. A contribution to the genetic characterization of some species of the genus Gobio (Cyprinidae). Folia Zoologica 53: 433-436.

Danilkiewicz Z. 1997. Lampreys and fishes of the river Bug and its Polish tributaries. Archives of Polish Fisheries 5: 5-82.

Doadrio I., Madeira M.J. 2004. A new species of the genus Gobio Cuvier, 1816 (Actinopterygii, Cyprinidae) from the Iberian Peninsula and southwestern France. Graellsia 60: 107-116.

Freyhof J., Scholten M., Bischofa A., Wanzenböck J., Staas S., Wolter C. 2000. Extensions to the known range of the whitefin gudgeon in Europe and biogeographical implications. Journal of Fish Biology 57: 1339-1342.

Froese R., Pauly D. (eds.) 2008. FishBase. Version 02/2008. www.fishbase.org

Gąsowska M. 1962. Klucze do oznaczania kręgowców Polski. [The keys for identification of vertebrates of Poland.] Part I. Kragłouste i ryby - Cyclostomi et Pisces. [Cyclostomes and fishes - Cyclostomi et Pisces.] PWN, Warszawa. [In Polish.]

Hensel K. 1978. Morphology of lateral-line canal system of the genera Abramis, Blicca and Vimba with regard to their ecology and systematic position. Acta Universitatis Carolinae Biologica 1975-1976: 105-149.

Hosoya K. 1986. Interrelationships of the Gobioninae (Cyprinidae). Pp. 484-501. In: Uyeno T., Arai R., Taniuchi T., Matsuura K. (eds.) Indo-Pacific fish biology: Proceedings of The Second International Conference on Indo-Pacific Fishes. Ichthyological Society of Japan, Tokyo.

Jarzynowa B., Rechulicz J. 1997. Pokrój klenia - Leuciscus cephalus (L.), piekielnicy - Alburoides bipunctatus (Bloch) i kiełbia - Gobio gobio (L.) z rzeki Bukowej na podstawie cech mierzalnych. [The body shape and proportions of European chub, Leuciscus cephalus; spirlin, Alburnoides bipunctatus; and gudgeon, Gobio gobio from the Bukowa River on the basis of measurable features.] Pp. 107-111.
In: Systematyka i filogeneza świata zwierzęcego. Systematyka ryb karpiowatych Cyprinidae. III Sesja Sympozjum, Olsztyn-Kortowo. [Systematics and phylogenatics of the animal kingdom. Systematics of cyprinid fishes. 3rd Session of the Symposium, Olsztyn-Kortowo.] 8 April 1997. [In Polish.]

Kirtiklis L., Boroń A., Porycka K. 2005. Chromosome banding patterns of the gudgeon, Gobio gobio (Actinopterygii, Cyprinidae). Acta Ichthyologica et Piscatoria 35: 119-123.

Kottelat M. 1997. European freshwater fishes. Biologia 52 (Suppl. 5): 1-271.

Kottelat M., Persat H. 2005. The genus Gobio in France, with redescription of G. gobio and description of two new species (Teleostei: Cyprinidae). Cybium 29: 211-324.

Kux Z., Libosvarsky J. 1981. Variable morphological characters of Gobio gobio (Cyprinidae) examined by principal component analysis. Folia Zoologica 30: 229-240.

Libosvarsky J., Kux Z. 1982. Multivariate analysis of five morphometric characters in the genus Gobio. Folia Zoologica 31: 83-92.

Naseka A.M. 1996. Comparative study on the vertebral column in the Gobioninae (Cyprinidae, Pisces) with special reference to its systematics. Publicaciones Especiales del Instituto Español de Oceanografía 21: 149-167.

Naseka A.M. 1998. Gobioninae. Pp. 81-87. In: Annotated check-list of Cyclostomata and fishes of the continental waters of Russia. Nauka, Moskva.

Naseka A.M., Bogutskaya N.G. 1998. A new gudgeon species Romanogobio pentatrichus (Gobioninae, Cyprinidae) from the basin of the Kuban River. Journal of Ichthyology 38: 173-181.

Naseka A.M., Erk'akan F., Küçük F. 2006. A description of two new species of the genus Gobio from Central Anatolia (Turkey) (Teleostei: Cyprinidae). Zoosystematica Rossica 15: 185-194.

Nelson J. 2006. Fishes of the world. John Wiley and Sons, New York.

Nowak M., Popek W., Drąg-Kozak E., Epler P. 2008. Morphology of the common gudgeon, Gobio gobio (Linnaeus, 1758) sensu lato, from the Vistula River drainage in the context of recent literature data (Teleostei: Cyprinidae). Archives of Polish Fisheries 16: 37-48.

Nowak M., Popek W., Epler P. 2006. The genus Gobio in Poland-historical review and present status (Teleostei, Cyprinidae). Acta Ichtiologica [sic] Romanica 1: 203-214.

Ramaswami L.S. 1955. Skeleton of cyprinoid fishes in relation to phylogenetic studies. 6 . The skull and Weberian apparatus in the subfamily Gobioninae (Cyprinidae). Acta Zoologica 36: $127-158$.

Rolik H. 1965. Materiały dotyczące zmienności geograficznej i ekologicznej Gobio gobio (L.) w Polsce. [A contribution to the knowledge of geographical and ecological variability of Gobio gobio (L.) in Poland.] Fragmenta Faunistica 12 (2): 15-29. [In Polish.]

Rolik H. 1967. Materiały do ichtiofauny Strwiąża (dopływ Dniestru) ze szczególnym uwzględnieniem Gobio gobio (L.) i Cobitis (Sabanejewia) aurata Fil. [New data on fish fauna of the Strwiąża River (the Dniestr River tributary) with par- 
ticular emphasis on Gobio gobio (L.) and Cobitis (Sabanejewia) aurata Fil.] Fragmenta Faunistica 14: 133-151. [In Polish.]

Ruchin A.B., Naseka A.M. 2003. Morphological characteristics of two sympatric gudgeons from the Sura River (Mordovia). Journal of Ichthyology 43: 279-282.

Schreiber A. 2000. Differences in levels of heterozygosity in populations of the common gudgeon (Gobio gobio, Cyprinidae) among adjacent drainages in central Europe: an effect of postglacial range dynamics? Heredity 89: 163-170.

Skóra S., Włodek J.M. 1966. Kiełb krótkowąsy (Gobio gobio L.) z rzeki Soły. Der Gründling (Gobio gobio L.) aus SołaFluss. Acta Hydrobiologica 8: 25-40.

Skóra S., Włodek J.M. 1969. The gudgeon [Gobio gobio (L.)] from the Dunajec River basin. Věstník Československé Společnosti Zoologické 33, 4: 351-368.

Skóra S., Włodek J.M. 1971. Kiełb krótkowąsy (Gobio gobio L.) z dorzeczy Czarnej Staszowskiej i Kamiennej. [Gudgeon (Gobio gobio L.) from the Czarna Staszowska River- and the Kamienna River systems.] Acta Hydrobiologica 13: 87-105. [In Polish.]

Szlachciak J. 2000. Kształt ciała, ubarwienie, cechy biometryczne i merystyczne. [Body shape, colouration, biometric and meristic characters.] Pp. 49-68. In: Brylińska M. (ed.) Ryby słodkowodne Polski. [The freshwater fishes of Poland.] PWN, Warszawa. [In Polish.]
Vandewalle P. 1974. Contribution à l'étude anatomique et fonctionnelle de la région céphalique de Gobio gobio (L.) (Pisces, Cyprinidae). 2. La chambre trigémino-faciale et quelques structures voisines. Forma et Functio 7: 119-124.

Vasil'eva E.D., Kuga T.I. 2005. Craniological features as available diagnostic characters for the short-barb Crimean gudgeon Gobio krymensis (Gobioninae, Cyprinidae). Folia Zoologica 54 (Suppl. 1): 33-41.

Vasil'eva E.D., Vasil'ev V.P., Boltachev A.R. 2005. Taxonomic relationships of gudgeons (Gobio, Gobioninae, Cyprinidae) of Crimea. Journal of Ichthyology 45: 730-743.

Vasil'eva E.D., Vasil'ev V.P., Kuga T.I. 2004. On taxonomy of gudgeons of the genus Gobio (Gobioninae, Cyprinidae) of Europe: A new gudgeon species Gobio kubanicus from the basin of the Kuban River. Journal of Ichthyology 44: 716-731.

Yang J., He S., Freyhof J., Witte K., Liu H. 2006. The phylogenetic relationships of the Gobioninae (Teleostei: Cyprinidae) inferred from mitochondrial cytochrome $b$ gene sequences. Hydrobiologia 553: 255-266.

Received: 19 February 2008 Accepted: 21 April 2008 Published electronically: 20 June 2008 